\title{
Successful mobilization using a combination of plerixafor and G-CSF in pediatric patients who failed previous chemomobilization with G-CSF alone and possible complications of the treatment
}

Kyung Taek Hong, Hyoung Jin Kang ${ }^{*}$, Nam Hee Kim, Min Sun Kim, Ji Won Lee, Hyery Kim, Kyung Duk Park, Hee Young Shin and Hyo Seop Ahn

\begin{abstract}
Peripheral blood stem cell (PBSC) mobilization, which uses plerixafor (AMD 3100), a newly developed specific inhibitor of the CXCR4 receptor, in combination with granulocyte-colony stimulating factor(G-CSF), has been shown to enhance the stem cell mobilization in adult patients, but pediatric data are scarce. We documented our experience with this drug in 6 Korean pediatric patients who had failed in chemomobilization, using G-CSF, alone. All patients were mobilized CD34 $4^{+}$cells (median, $11.08 \times 10^{6} / \mathrm{kg}$ : range, $6.34-28.97 \times 10^{6} / \mathrm{kg}$ ) successfully within 2 to 3 cycles of apheresis, without complications. A total of 7 autologous transplantations were performed, including 1 tandem transplantation. However, 2 patients with brain tumors showed severe pulmonary complications, including spontaneous pneumomediastinum. This is the first study of PBSC mobilization with plerixafor in Asian pediatric patients. Furthermore our study suggests that mobilization with plerixafor may be effective in Korean pediatric patients, who have previously been heavily treated and have failed PBSC mobilization with classical chemomobilization, using G-CSF. However, further studies are needed to examine the possible complications of autologous transplantation, using a mobilized plerixafor product in children.
\end{abstract}

Keywords: Plerixafor, Hematopoietic Stem Cell Mobilization, Pediatrics, Complications, Interstitial Lung Diseases

\section{Letter to the editor}

Plerixafor has been introduced for the mobilization of hematopoietic stem cells to peripheral blood, by interfering with the SDF1-CXCR4 interaction. Although it has been FDA-approved in adult patients with nonHodgkin lymphoma or multiple myeloma [1,2], the pediatric data usage are scarce, particularly in Asian children [3-8].

We retrospectively reviewed all 6 patients ( 3 males, 3 females), who received plerixafor-based mobilization at our center after obtaining the Institutional Review Board approval (H-1108-103-374). They had all

\footnotetext{
* Correspondence: kanghj@snu.ac.kr

Department of Pediatrics, Cancer Research Institute, Seoul National University College of Medicine, Seoul, Republic of Korea
}

previously failed peripheral blood stem cell (PBSC) mobilization by chemotherapy and G-CSF. The patient's characteristics, previous treatments and mobilization chemotherapies are shown. (Table 1) All patients received G-CSF $(10 \mu \mathrm{g} / \mathrm{kg})$ for 4 days, without prior chemotherapy. Then plerixafor $(240 \mu \mathrm{g} / \mathrm{kg}$; Mozobil, Genzyme Inc, Naarden, The Netherlands) and G-CSF (10 $\mu \mathrm{g} / \mathrm{kg}$ ) were administered subcutaneously, at 10 and 2 hours before each apheresis. CD34 ${ }^{+}$cells (median, 11.08 $\times 10^{6} / \mathrm{kg}$; range, $6.34-28.97 \times 10^{6} / \mathrm{kg}$ ) were mobilized successfully in all patients, after 2 to 3 apheresis without immediate complications (for each apheresis: mean, 6.28 $\times 10^{6} / \mathrm{kg}$ : range, $3.17-14.49 \times 10^{6} / \mathrm{kg}$ ). Seven autologous stem cell transplantations were performed, including 1 tandem transplantation, and the results of engraftment were acceptable. (Table 2) 
Table 1 Patient Demographics and Prior Treatment Received

\begin{tabular}{|c|c|c|c|c|c|c|}
\hline $\begin{array}{l}\mathrm{Pt} \\
\#\end{array}$ & Dx & Sex & Age & Earlier chemotherapy & $\begin{array}{l}\text { Earlier } \\
\text { radiotherapy }\end{array}$ & $\begin{array}{l}\text { 1st line mobilization } \\
\text { chemotherapy }\end{array}$ \\
\hline 1 & NBL & M & 11 & $\mathrm{CDDP}+\mathrm{VP} 16+\mathrm{ADR}+\mathrm{CPM}, \mathrm{CPM}+\mathrm{Topo}+\mathrm{VP} 16$ & No & CPM + VP16+ GCSF \\
\hline 2 & MBL & $\mathrm{F}$ & 11 & $C D D P+C P M+V C R, C P M+V C R$, Carbo $+V P 16+I F M+V C R$ & $\mathrm{IFRT}+\mathrm{CSI}$ & $\begin{array}{l}\text { Carbo + VP16 + IFM + } \\
\quad \text { VCR + GCSF }\end{array}$ \\
\hline 3 & OSA & M & 6 & $\mathrm{CDDP}+\mathrm{ADR}+\mathrm{MTX}, \mathrm{IFM}+\mathrm{ADR}+\mathrm{MTX}$ & No & CPM + VP16+ GCSF \\
\hline 4 & OSA & $\mathrm{F}$ & 10 & $\begin{aligned} & \text { CDDP + ADR + MTX, IFM + } \text { ADR + MTX, Gemcitabine + Doxetaxel, CPM + Topo + } \\
& \text { VP16, IFM + Carbo + VP16 }\end{aligned}$ & No & $\mathrm{CPM}+\mathrm{VP} 16+\mathrm{GCSF}$ \\
\hline 5 & MBL & M & 10 & $C D D P+C P M+V C R, C P M+V C R$ & IFRT + CSI & $\begin{array}{l}\text { Carbo + VP16 + IFM + } \\
\quad \text { VCR + GCSF }\end{array}$ \\
\hline 6 & ES & $\mathrm{F}$ & 15 & $\mathrm{VCR}+\mathrm{ADR}+\mathrm{CPM}, \mathrm{IFM}+\mathrm{VP} 16$ & No & $C P M+V P 16+$ GCSF \\
\hline
\end{tabular}

ADR Doxorubicin, Carbo Carboplatin, CDDP Cisplatin, CPM cyclophosphamide, CSI Craniospinal axis irradiation, ES Ewing sarcoma, G-CSF Granulocyte colony stimulating factor, IFM Ifosphamide, IFRT Involved field radiation therapy, LP Leukapheresis, MBL Medulloblastoma, MTX Methotrexate, NBL Neuroblastoma, OSA Osteosarcoma, Pt Patient, Topo Topotecan, VCR Vincristine, VP16 Etoposide

Table 2 PBSC Collection and Engraftment

\begin{tabular}{|c|c|c|c|c|c|c|c|c|c|}
\hline \multirow[b]{2}{*}{$\begin{array}{l}\mathrm{Pt} \\
\#\end{array}$} & \multirow[b]{2}{*}{$\begin{array}{c}\text { Prior CD34 } \\
\text { yield }\left(10^{6} \mathrm{CD} 34+\right. \\
\text { cells } / \mathrm{kg})\end{array}$} & \multirow[b]{2}{*}{$\begin{array}{l}\text { Days for } \\
\text { LP }\end{array}$} & \multicolumn{4}{|c|}{ Plerixafor-based PBSC collection } & \multicolumn{3}{|c|}{ Engraftment } \\
\hline & & & $\begin{array}{l}\text { CD34+ cells } \\
\left(10^{6} / \mathrm{kg}\right)\end{array}$ & $\begin{array}{l}\text { TNC } \\
\left(10^{8} /\right. \\
\mathrm{kg})\end{array}$ & $\begin{array}{l}\text { Days for } \\
\text { LP }\end{array}$ & $\begin{array}{c}\text { TPL } \\
\#\end{array}$ & $\begin{array}{c}\text { PBSC infused } \\
\left(10^{6} \text { CD34+ }\right. \\
\text { cells } / \mathrm{kg})\end{array}$ & $\begin{array}{c}\text { ANC }>500 / \mathrm{mL} \\
\text { (days) }\end{array}$ & $\begin{array}{c}\text { PLT }>20,000 / m L \\
\text { (transfusion- } \\
\text { independent)(days) }\end{array}$ \\
\hline \multirow[t]{2}{*}{1} & 1.24 & 4 & 12.64 & 16.13 & 3 & $\# 1$ & 5.91 & 10 & 35 \\
\hline & & & & & & $\# 2$ & 3.48 & 9 & 197 \\
\hline 2 & 0.18 & 2 & 9.52 & 11.2 & 2 & & 4.8 & 10 & 26 \\
\hline 3 & 1.68 & 2 & 6.81 & 10.67 & 2 & & 8.49 & 10 & 15 \\
\hline 4 & 0.7 & 3 & 6.34 & 15.1 & 2 & & 7.04 & N/A & N/A \\
\hline 5 & 4 & 4 & 28.97 & 20.25 & 2 & & 17.78 & 10 & N/A \\
\hline 6 & 0.8 & 3 & 15.25 & 17.83 & 2 & & 3.74 & 12 & 18 \\
\hline
\end{tabular}

ANC Absolute Neutrophil Count, LP Leukapheresis, N/A Not Applicable (due to early death), PBSC Peripheral Blood Stem Cell, PLT Platelet, Pt, Patient, TNC Total Nuclear Cells, TPL Transplantation

Patients \#1, \#3 and \#6 were disease-free at the last follow-up (28, 12 and 3 months after transplantation, respectively), however, patient \#4 died on day 3 , due to sudden cardiac arrest. Interestingly, two medulloblastoma patients (patients \#2 and \#5) showed serious lung problems, which include spontaneous pneumomediastinum on day 56 and 11, died on day 102 and 89, respectively. The cause of death of both patients showed to be respiratory failure, of which, the pathogen was not revealed by bronchoalveolar lavage or lung biopsy. The pathologic finding was consistent with a diffuse alveolar damage. In our center, 6 other patients who underwent the same radiotherapy and autologous PBSC transplantation, with the same conditioning regimen, but did not receive plerixafor for mobilization, have not shown such fatal pulmonary complication (data not shown). Due to the plerixafor mobilization of the different cell populations, in comparison with G-CSF alone $[9,10]$, unexpected complications might occur after infusion in susceptible recipients, like the 2 patients that were mentioned above who underwent irradiation around the thoracic area.
In conclusion, we report the first data of Asian pediatric usage of plerixafor for PBSC mobilization, which showed a success rate of $100 \%$, without acute complications. This is a higher success rate than those in the previous pediatric studies [3,7]. However we experienced two patients with medulloblastoma, who suffered from fatal pulmonary complication. Though the pathogenesis was not understood, further studies are needed to investigate possible complications of plerixafor in pediatric patients.

\section{Conflict of interest}

The authors declare that they have no competing interests.

\section{Abbreviations}

SDF1: Stromal cell-derived factor 1; CXCR4: CXC chemokine receptor 4; PBSC: Peripheral blood stem cell; G-CSF: Granulocyte colony stimulating factor.

\section{Acknowledgements}

We thank the patients, families and clinicians who contributed to this study. This study was supported by grant no 03-2011-0420 from SNUH Research Fund and by grant of the Korea Healthcare Technology R\&D Project, Ministry of Health \& Welfare, Republic of Korea. (A102065) 


\section{Authors' contributions}

$\mathrm{KTH}$ collected and analyzed the patient data and wrote the manuscript, NHK, MSK collected the patient data, JWL, HK, KDP, HYS, HSA assisted the data interpretation, and HJK designed and coordinated the study. All authors have read and approved the final manuscript.

Received: 20 March 2012 Accepted: 30 March 2012

Published: 30 March 2012

\section{References}

1. DiPersio JF, Micallef IN, Stiff PJ, Bolwell BJ, Maziarz RT, Jacobsen E,

Nademanee A, McCarty J, Bridger G, Calandra G: Phase III Prospective Randomized Double-Blind Placebo-Controlled Trial of Plerixafor Plus Granulocyte Colony-Stimulating Factor Compared With Placebo Plus Granulocyte Colony-Stimulating Factor for Autologous Stem-Cell Mobilization and Transplantation for Patients With Non-Hodgkin's Lymphoma. J Clin Oncol 2009, 27:4767-4773.

2. DiPersio JF, Stadtmauer EA, Nademanee A, Micallef INM, Stiff PJ, Kaufman JL, Maziarz RT, Hosing C, Fruehauf S, Horwitz M, et al: Plerixafor and G-CSF versus placebo and G-CSF to mobilize hematopoietic stem cells for autologous stem cell transplantation in patients with multiple myeloma. Blood 2009, 113:5720-5726.

3. Aabideen $\mathrm{K}$, Anoop P, Ethell ME, Potter MN: The feasibility of plerixafor as a second-line stem cell mobilizing agent in children. J Pediatr Hematol Oncol 2011, 33:65-67.

4. Alejandra Bernardo V, Szechung Ng J, Joyce MJ: Use of Plerixafor with Granulocyte Colony-Stimulating Factor for Stem Cell Mobilization in a Pediatric Patient (February). Ann Pharmacother 2011, 45:e12.

5. Cardenoux C, Oudot C, Deméocq F, Roussanne M-C, Piguet C, Kanold J, Merlin E: Pegfilgrastim plus AMD 3100 for stem-cell mobilization in children. Pediatr Blood Cancer 2010, 55:769.

6. Flatt T, Lewing K, Gonzalez C, Anthony K, Ryan R, Jones R, Gamis A, Dalal J: Successful mobilization with AMD3100 and filgrastim with engraftment of autologous peripheral blood stem cells in a heavily pretreated pediatric patient with recurrent Burkitt lymphoma. Pediatr Hematol Oncol 2010, 27:138-149.

7. Modak S, Cheung IY, Kushner BH, Kramer K, Reich L, Cheung N-KV: Plerixafor plus granulocyte-colony stimulating factor for autologous hematopoietic stem cell mobilization in patients with metastatic neuroblastoma. Pediatr Blood Canc 2011, 58:469-471.

8. Toledano H, Yahel A, Cohen IJ, Yaniv I, Stein J: Successful mobilization, harvest and transplant of peripheral blood stem cells using AMD3100 and G-CSF following high dose craniospinal irradiation for medulloblastoma in a young child. Pediatr Blood Cancer 2010, 54:613-615.

9. Devine SM, Vij R, Rettig M, Todt L, McGlauchlen K, Fisher N, Devine H, Link DC, Calandra G, Bridger G, et al: Rapid mobilization of functional donor hematopoietic cells without G-CSF using AMD3100, an antagonist of the CXCR4/SDF-1 interaction. Blood 2008, 112:990-998.

10. Donahue RE, Jin P, Bonifacino AC, Metzger ME, Ren J, Wang E, Stroncek DF: Plerixafor (AMD3100) and granulocyte colony-stimulating factor (G-CSF) mobilize different CD34+ cell populations based on global gene and microRNA expression signatures. Blood 2009, 114:2530-2541.

\section{doi:10.1186/1756-8722-5-14}

Cite this article as: Hong et al: Successful mobilization using a combination of plerixafor and G-CSF in pediatric patients who failed previous chemomobilization with G-CSF alone and possible complications of the treatment. Journal of Hematology \& Oncology 2012 5:14.

\section{Submit your next manuscript to BioMed Central and take full advantage of:}

- Convenient online submission

- Thorough peer review

- No space constraints or color figure charges

- Immediate publication on acceptance

- Inclusion in PubMed, CAS, Scopus and Google Scholar

- Research which is freely available for redistribution 